TI 2014-047/ VIII

Tinbergen Institute Discussion Paper

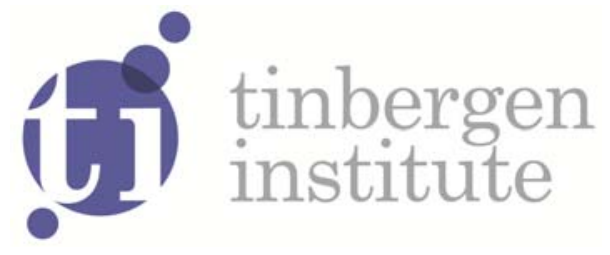

\title{
The Value of Proximity to Water in Residential Areas
}

\author{
Jan Rouwendal 1,2 \\ Ramona van Marwijk ${ }^{3}$ \\ Or Levkovich'
}

' Faculty of Economics and Business Administration, VU University Amsterdam,

2 Tinbergen Institute,

${ }_{3}$ Kadaster, Netherlands Cadastre, Land Registry and Mapping Agency, the Netherlands. 
Tinbergen Institute is the graduate school and research institute in economics of Erasmus University Rotterdam, the University of Amsterdam and VU University Amsterdam.

More TI discussion papers can be downloaded at http://www.tinbergen.nl

Tinbergen Institute has two locations:

Tinbergen Institute Amsterdam

Gustav Mahlerplein 117

1082 MS Amsterdam

The Netherlands

Tel.: +31(0)205251600

Tinbergen Institute Rotterdam

Burg. Oudlaan 50

3062 PA Rotterdam

The Netherlands

Tel.: +31(0)10 4088900

Fax: $+31(0) 104089031$

Duisenberg school of finance is a collaboration of the Dutch financial sector and universities, with the ambition to support innovative research and offer top quality academic education in core areas of finance.

DSF research papers can be downloaded at: http://www.dsf.nl/

Duisenberg school of finance

Gustav Mahlerplein 117

1082 MS Amsterdam

The Netherlands

Tel.: +31(0)20 5258579 


\title{
The value of proximity to water in residential areas
}

\author{
Jan Rouwendal ${ }^{\mathrm{a}, \mathrm{c}}$, Ramona van Marwijk ${ }^{\mathrm{b}}$, Or Levkovich ${ }^{\mathrm{a}}$ \\ ${ }^{a}$ Department of Spatial Economics, VU University, Amsterdam \\ ${ }^{b}$ Kadaster / Netherlands Cadastre, Land Registry and Mapping Agency \\ ${ }^{c}$ Tinbergen Institute, the Netherlands
}

\begin{abstract}
Proximity to water is appreciated by households. Hedonic analyses that try to measure the value of this amenity are potentially biased by omitted variables as locations close to the water may be selected by households with higher incomes who construct more luxury houses. Since it is difficult to observe all relevant characteristics, the coefficient for proximity to water may be biased upwards. We circumvent this problem by exploiting a specific characteristic of the Dutch system of planned residential development: often a number of identical houses are constructed close to each other. By comparing the values of such identical houses, we can measure the effect of proximity to water under almost ideal circumstances. The results show a significant impact of this amenity, but of a smaller magnitude than was suggested by many earlier studies, thereby confirming the conjectured presence of omitted variable bias.
\end{abstract}

\section{Introduction}

The purpose of hedonic analysis is often to measure the marginal willingness to pay for a public good or an external effect like the proximity to a park or aircraft noise. This is usually complicated by the extreme heterogeneity of the housing stock. In general, it is difficult to find identical houses and even if there are no differences in observed characteristics there can be considerable differences in unobserved attributes. These unobserved attributes are a potential cause of omitted variable bias in the coefficients of the hedonic price function and in the marginal willingness to pay measures based on them. In this paper we explore a possibility to circumvent this problem by concentrating on newly developed residential areas in the Netherlands. It is often the case that a limited number of dwelling types are made available on these sites and that a - possibly large - number of each type is constructed. The technical attributes of units of the same type are identical, and this means that a major source of unobserved heterogeneity is absent. Moreover, these houses are located close to each other,

Email addresses: j.rouwendal@vu.nl (Jan Rouwendal), ramona.vanmarwijk@kadaster.nl (Ramona van Marwijk), o.d.Levkovich@vu.nl (Or Levkovich) 
implying that neighborhood characteristics are also equal. To reduce the risk that houses that were initially identical have become different because of later investments we restrict the analysis to houses that have been constructed less than 15 years before transaction prices were observed. These houses, which are identical in so many respects, may nevertheless differ in their proximity to water and this gives us the opportunity to measure the impact of this amenity under conditions that are close to ideal. That is the research strategy that we follow in this paper.

\section{Effects measured in previous literature, and the methods that were used}

Several researchers applied hedonic models to measure the effect of water on residential property values and most of them found value-increasing effects of water on house prices.

Lansford and Jones (1995) used hedonic regression to measure the effects of proximity to water in the Colorado River basin (Texas). For the estimation of the hedonic regression they used a Box-Cox transformation of the dependent variable and of the continuous distance variable. They also consider that proximity to water may have very little influence on properties which are located over 4,000 feet from water, and therefor include a dummy variable in order to capture the effect of proximity to water in such distance ranges. They found that an increase in one feet distance to a lake is expected to lead to a $3.1 \%$ decrease in housing price (which is equivalent to approximately $-10 \%$ in one meter increase).

Doss and Taff (1996) examined the value of urban wetlands, including lakes in Ramsey County, Minnesota. Focusing on property with a wetland within a range of 1,000 meters around it, and considering distance as a linear-continuous variable, they found a large effect of lake view on house values. They discovered implicit prices of $\$ 46,000$ for an average property value of $\$ 105,000$, indicating a value increase of $43.8 \%$ and a smaller effect of distance to lakes - an additional 10 meters closer to a lake is worth $\$ 188$. A similar large positive waterfront effect $(31,7 \%)$ was found by Geoghegan et al. (1997) in a region within a 30-mile radius of Washington DC.

Other positive proximity to water effects were found by Mahan et al. (2000) for wetlands in Portland, Oregon. Using a natural logarithm transformation of the distance variable, they found relatively smaller effects of proximity to water - distance-price elasticities of $7 \%$ for lakes, $1.1 \%$ for streams and $1.8 \%$ for wetlands, based on initial distance of one mile.

Assuming more flexibility by distance levels of the effect of proximity to water on housing value, Orford (2002) studied the effects of proximity to River Taff in Cardiff, UK, using distance dummy variables in 50 meter intervals. The results showed that a house which is located within $50 \mathrm{~m}$ from the river is expected to be nearly $£ 9000$ higher $(16.8 \%)$, compared with houses in other locations.

It is likely to expect that water bodies in different spatial locations may have dissimilar effects on the prices of housing in their vicinity. In this respect, a 
Dutch canal or a lake may be not be valued similarly as other bodies of water in the US or the UK. However, Luttik (2000) studied the effects of proximity to water in four locations in The Netherlands and found that the effects of proximity to water on housing price in the Netherlands are relatively similar to the effects measured in other locations. Her results indicate positive price effects of water in residential areas, ranging from $7 \%$ for water within $1000 \mathrm{~m}$ to $10 \%$ for water views.

Cho et al. (2006) also estimated the contribution of water to housing values in multiple places. They specify the house value and distance variables in logarithmic form, and use both standard OLS and locally weighted regressions to estimate the effects of water and green space amenities on housing values in Know County, Tennessee. The global model found a distance to water effect of $-2.0 \%$, using an initial distance of one mile. The local model however showed regional differences with both positive and negative effects of proximity to water ranging from $-9.0 \%$ to $+2.1 \%$. They explain that the variation in results in the local model may result from a variation in the size of water bodies and the consequent presence of other positive and attractive amenities in the area.

Anderson and West (2006) conducted an hedonic analysis with US censusblock fixed-effects in order to examine the effects of proximity to open-space amenities on housing transaction price. Following estimation of flexible-form models with Box-Cox transformations, they defined the distance variable as logarithm since they were unable to reject a log-log relationship. They find price-distance elasticity of -0.034 for proximity to a lake, and -0.027 for proximity to a river. Moreover, they also find that omitting local fixed effects and replacing them with neighborhood control variable causes a bias and in some cases reverses the sign of the estimated effects.

While almost all studies show positive effects of water on housing values, the size of the effects varies greatly, with distance price elasticities ranging from $-9,0 \%$ to $43.8 \%$. Moreover, while waterfront locations are particularly valuable, price effects are found to be present in distances of one mile. Goetgeluk et al. (2005) conclude that the added value of water in residential environments is highly context-dependent. However, although most studies used housing and neighborhood characteristics as control variables in the hedonic analysis, omitted variable bias could still provide explanation to the differences in estimated results (as was shown in (Cho et al., 2006; Anderson and West, 2006)). In addition, the studies mentioned above also vary in their definition of the functional relationship between proximity to water and housing value. misspecification of the hedonic price function can seriously undermine its ability to accurately estimate actual willingness-to-pay (Kuminoff et al., 2010; Halvorsen and Pollakowski, 1981; Cheshire and Sheppard, 1995). Often, perhaps inevitably, data availability rather than sound theoretical grounding influences hedonic model specification (Bryant and Eves, 2013). In this paper we address the concerns of omitted variable bias by the use of fixed effects, in a unique spatial setting which allows a very restrictive definition of the fixed-effects groups. Moreover, in order to improve the quality and robustness of the estimated coefficients, we also introduce flexibility in the relationship between price and proximity to water. 
This is addressed by estimating several hedonic specifications in which we reduce restrictions on the functional form of the variables.

\section{Research methods}

\subsection{Design of the study}

As previously mentioned, omitted variable bias is often an important concern with hedonic price analyses. In practice it is hard to make sure that one has controlled for all the relevant characteristics of the houses. For instance, proximity to water makes a site more attractive and therefore be bought by people with higher incomes who built more luxury houses. Not all the relevant characteristics may be easily observed and the result may be that part of the impact of the more luxurious housing is captured in the coefficient for proximity to water. This effect may also be present in countries like the Netherlands where residential development is planned. The costs and revenues of such plans are important and the preferences of households for proximity to water and luxury characteristics are at least to some extent known by the planners and may be exploited in order to increase the revenues of the project.

Ideally, we should be able to compare houses that are identical in all respects except for their proximity to water to measure the effect of this characteristic properly. Fortunately, the Dutch planning system allows us to come very close to this ideal. One consequence of the planned nature of residential development in the Netherlands is that often a number of exactly the same houses are constructed. These houses are exactly equal in floor area, number of rooms, and all kinds of other characteristics. If two of such identical houses differ in their proximity to water this offers an excellent opportunity to measure the value of this amenity. This is what we do in this paper.

\subsection{Fixed-effects model}

In this paper we apply several versions of a fixed-effects model. The fixedeffects model takes advantage of the panel form of the data, in order to control for the fixed characteristics which affect prices of houses, but remain constant over similar objects or neighborhoods. Controlling for these fixed-effects is an important factor in this research, since it reduces the suspicion of an estimator bias. Although the study neighborhoods were chosen based on the condition that properties will be equal in housing characteristics, the properties in each of the neighborhoods still differ from each other both in observed and unobserved characteristics. This is efficiently handled using the fixed-effect model. In the set up process of the model we first constructed groups of similar properties which have similar characteristics but differ in their proximity to water. The selection of groups of houses was based on each unique combination of municipality and neighborhood affiliation, year of construction, housing type and floor area, and is described in further details in section 4.

In order to examine the effect of proximity to water from other possible angles, we use several specifications of the fixed-effects model. The purpose of 
the multiple specifications is to increase the flexibility of the estimated values, and to lower the restrictions on the functional relationship between the distance to water and the transaction price.

In the first specification we use a traditional fixed-effects specification with distance included in continuous variable form (1):

$$
\ln \left(\tilde{P}_{i}\right)=\beta_{d} \tilde{d}_{i}+\beta_{z} \tilde{Z}_{i}+\sum_{t}^{T} \beta_{t} \tilde{Y_{t, i}}+\epsilon_{i}
$$

Where $P_{i}$ is the transaction price of property $i, Z_{i}$ denoted parcel size, and $d_{i}$ is distance in meters from a type of water. $\sum_{t}^{T} \beta_{t} \tilde{Y}_{t, i}$ denotes a list of year dummies which take the value of 1 according to the year in which the housing transaction occurred, and zero otherwise. For simplification, we denote the deviations from the group-mean value of each house $i$ from with tilde accent as following: $\tilde{d}_{i}=d_{i}-\bar{d}_{i}$.

A second approach involves estimating the effect of proximity to water in different distance range groups, defined by fixed distance intervals. The specification in (2) allows more flexibility for the estimated distance effect coefficients, and it no longer imposes linearity with distance in the estimated effect. Each coefficient now captures the effect of proximity to water for groups of houses which are located in 10 meter intervals from water, by representing these groups with distance dummy variables:

$$
\ln \left(\tilde{P}_{i}\right)=\beta_{10 m} I_{10 m}+\beta_{20 m} I_{20 m}+\beta_{30 m} I_{30 m}+\beta_{40 m} I_{40 m}+\beta_{50 m} I_{50 m}+\beta_{z} \tilde{Z}_{i}+\sum_{t}^{T} \beta_{t} \tilde{Y}_{t, i}+\epsilon_{i}
$$

Where $I_{10 m}-I_{50 m}$ are indicator variables which are equal to 1 if house i is located within 10-50 meters from a body of water (respectively), and are equal to zero otherwise.

\subsection{Semi-parametric model specification}

The specifications presented above differ in the level of flexibility they allow for the relations between the proximity to water and the house transaction price, but they all impose a functional form on these relations. In order to improve our understanding of the relations between these variable we suggest testing a semi-parametric regression. A semi-parametric regression treats the explanatory variable as an unknown function, and estimates its value without specifying its functional form (3):

$$
P_{i}=f\left(d_{i}\right)+\beta_{z} Z_{i}+\beta_{w} W_{i}+\sum_{k} \beta_{k} X_{k, i}+\epsilon_{i}
$$

The semi-parametric specification no longer utilizes the panel structure of the data. Therefore, in order to maintain consistency in the identification of housing groups, we define dummy variables for each housing group $k$ and include them as parametric variables in the regression, denoted as $X_{k, i}$. In the individual analysis for each of the water types, we define one water type to be estimated semi-parametrically while the other type is included as a parametric control 
variable $W_{i}$. In this specification, the transaction price is now defined as an unknown function of the distance to water, $f\left(d_{i}\right)$, and of parametric specifications of the other explaining variables. The transaction price variable is also no longer defined in its logarithmic values, since the semi-parametric regression ignores functional specifications. Although the results of the semi-parametric regression produce no coefficients for the effect of proximity to water, it can still teach about the nature of the relationship between the variables and point out which is the closest suitable functional form to describe them. In order to construct $95 \%$ confidence intervals, during the estimation of the semi-parametric specification we applied bootstrap sampling with 200 replicates, which allowed us to compute standard deviations of the estimated coefficients and the smoothed predicted price values (Efron, 1979).

In this research we also aim to make a distinction between the effects of different types of water bodies on housing types. Therefore, we separate the effect of proximity to a lake and proximity to water ways such as canals, rivers or channels. This distinction is repeated over each of the model specifications mentioned above in $(1,2$, and 3$)$.

\section{Data}

\subsection{Proximity to open water and planned residential development}

The Netherlands is a small country in North Western Europe. Ever since the late Middle Ages it has had a relatively high population density. Water is abundantly present in the Dutch landscape, especially in the western part of the country. Population growth has been relatively strong until the 1970s and the growth in the number of households has been even more pronounced. This gave rise to strong housing demand pressure. To facilitate these developments, the housing stock was increased. To a large extent this happened via planned construction of new neighborhoods. Usually this meant that a limited number of developers constructed the new housing on the basis of a plan that was agreed upon with the municipality that played a coordinating, and often also a steering role in the development of the new neighborhoods. These new residential areas were often carefully designed. Mixed housing supply was thought to be desirable to avoid the emergence of areas in which exclusively rich or poor people lived. This called for heterogeneous housing types so as to ensure that affordable housing for different socio-economic groups was available in these areas. On the other hand it was also advantageous to limit the number of different housing types as this reduced the design costs of these new areas. In the Dutch planning system, terraced housing occupies a prominent place and this reinforced the tendency to construct a relatively large number of identical houses in these new areas.

The Netherlands is also known as the lowlands and water a canal, a river, a pond or a lake - is often not far away. The presence of open water may make a site also more attractive as potential new residential areas. Moreover, the level of the ground water is high at many sites. This is certainly the case in many 
new residential areas and the construction of ponds facilitates the regulation of the ground water level while making the area more attractive as well. Of course, this does not mean that all the houses in these new residential areas are equally close to open water. Within a new residential area, identical houses may easily differ in their proximity to a body of water, for instance because the are both on different ends of a row of houses that starts close to open water. Having open water at a distance of 10 or 50 meters may make an important difference in the willingness to pay of households for this amenity. Houses which are closer to water have a view to the water, and properties adjacent to water may enjoy a direct access to water, and in some cases may also install a small leisure boat-dock. On the other hand, it should be noted that houses which are adjacent to water may also be subject to other related negative effects, such as drowning safety hazards or flood risks.

Table 1: Number of properties, by proximity to water types

\begin{tabular}{l|cc|cc|cc}
\hline $\begin{array}{l}\text { Distance range } \\
\text { (meters) }\end{array}$ & Any water type & cum. & Lakes & cum. & Waterways & cum. \\
\hline 0 distance & 920 & $5.4 \%$ & 115 & $0.7 \%$ & 805 & $4.7 \%$ \\
$1<10$ & 1,069 & $11.7 \%$ & 75 & $1.1 \%$ & 999 & $10.6 \%$ \\
$11<20$ & 1,428 & $20.0 \%$ & 113 & $1.8 \%$ & 1,329 & $18.4 \%$ \\
$21<30$ & 954 & $25.6 \%$ & 152 & $2.7 \%$ & 851 & $23.4 \%$ \\
$31<40$ & 1,002 & $31.5 \%$ & 104 & $3.3 \%$ & 951 & $28.9 \%$ \\
$41<50$ & 1,306 & $39.2 \%$ & 179 & $4.3 \%$ & 1,189 & $35.9 \%$ \\
$51<60$ & 936 & $44.7 \%$ & 198 & $5.5 \%$ & 822 & $40.7 \%$ \\
$61<70$ & 815 & $49.4 \%$ & 165 & $6.5 \%$ & 744 & $45.1 \%$ \\
$71<80$ & 729 & $53.7 \%$ & 161 & $7.4 \%$ & 667 & $49.0 \%$ \\
$81<90$ & 801 & $58.4 \%$ & 275 & $9.0 \%$ & 664 & $52.9 \%$ \\
$91<100$ & 638 & $62.1 \%$ & 184 & $10.1 \%$ & 573 & $56.3 \%$ \\
100 and more & 6,456 & $100.0 \%$ & 15,333 & $100.0 \%$ & 7,460 & $100.0 \%$ \\
\hline Total & 17,054 & & 17,054 & & 17,054 & \\
\hline
\end{tabular}

\subsection{Selection of the data}

Housing transaction data is taken from the database of Kadaster, the Dutch land registry and mapping agency. We selected 114 neighborhoods in 32 large cities in the Netherlands where open water was abundant. Types of water are divided to lakes and waterways, based on the Dutch land registery definitions. Waterways ("Waterloop") are defined as Elongated portion of water in the form of a river, stream or a canal, which are broader than 6 meters. Lakes ("Meer") is defined as a water body larger than $50 \mathrm{~m}^{2}$, which is not a watercourse. This definition may include lakes, ponds or reservoirs (both natural and artificially constructed). In the neighborhoods that were chosen for the research, (Table A.9 in the appendix provides the list) at least $70 \%$ of total properties are constructed since 1998. In the selected areas, 17,054 transactions refer to houses that were built in 1998 or later. Moreover, we excluded information about the first sale of the house, since it is likely that identical houses (but not in proximity to water) 
have been sold to the first occupiers at identical prices. It could also be the case that the price paid for the first sale was for the land only, while the construction of the house was paid to the developer. Thus, the selling price of the first sale may have not reflected the complete property value.

Table 1 shows that roughly $40 \%$ of these transactions refer to properties located within 50 meters distance from any type of water, as measured from the limits of the parcel of each property, and over $60 \%$ are located within 100 meters distance from water.

Our research design requires that we focus on the comparison of identical houses. To do so we defined homogeneous groups of house on the basis of the following conditions:

i Located in the same residential area

ii Identical floor area

iii Identical type, and

iv Identical year of construction.

Although this list of characteristics is short, it is powerful. In particular the requirement that the number of square meters of living space should match exactly is demanding. It is difficult to imagine that an arbitrary pair of houses constructed independently of each other fulfills all these requirements.

Table 2: Descriptive statistics of the housing characteristics

\begin{tabular}{lccccc}
\hline Variable & Obs & Mean & sd & Min & Max \\
\hline Housing price & 17054 & 278804 & 100850.1 & 49916 & 975000 \\
Year constructed & 17054 & 2000.642 & 2.003383 & 1998 & 2010 \\
Floor size & 17054 & 137.5161 & 37.8108 & 9 & 774 \\
Parcel size & 17054 & 219.689 & 159.9118 & 32 & 7698 \\
\hline
\end{tabular}

\begin{tabular}{lccc}
\hline Housing type & Freq. & Percent & Cum. \\
\hline Apartment & 296 & 1.74 & 1.74 \\
Corner house (Hoekwoning) & 3,170 & 18.59 & 20.32 \\
Two under same roof (2 onder 1 kap) & 1,391 & 8.16 & 28.48 \\
Terraced house (Tussenwoning) & 10,758 & 63.08 & 91.56 \\
Detached house (Vrijstaand) & 1,439 & 8.44 & 100 \\
Total & 17,054 & 100 & \\
\hline
\end{tabular}

Table 2 gives descriptive of the characteristics we use in defining our homogeneous groups as well as about the parcel size. We didn't use the latter variable for defining our groups, because is often happens that parcel size differ, for instance because streets are not exactly parallel while the houses on these parcels are exactly identical. We will use parcel size as a control variable in all regressions. Table 3 shows that our selection procedure results in the selection of 5,371 unique groups. roughly $50 \%$ of these groups ( $16 \%$ of the observed transactions) have only one observed transactions and they will not be used in 
the analysis that follows. In our 'fixed effects' regressions the variation within groups drives the estimation results. $50 \%$ of the transactions belong to groups with over 6 unique properties. The largest group includes 95 identical properties.

Table 3: Number of homogeneous groups

\begin{tabular}{ccccc}
\hline Group size & Freq. & Number of groups & Percentage & Cumulative percentage \\
\hline 1 & 2720 & 2720 & $16 \%$ & $16 \%$ \\
2 & 1970 & 985 & $12 \%$ & $28 \%$ \\
3 & 1428 & 476 & $8 \%$ & $36 \%$ \\
4 & 1224 & 306 & $7 \%$ & $43 \%$ \\
5 & 960 & 192 & $6 \%$ & $49 \%$ \\
6 & 756 & 126 & $4 \%$ & $53 \%$ \\
7 & 763 & 109 & $4 \%$ & $58 \%$ \\
8 & 520 & 65 & $3 \%$ & $61 \%$ \\
9 & 567 & 63 & $3 \%$ & $64 \%$ \\
10 to 19 & 3137 & 241 & $18 \%$ & $82 \%$ \\
20 to 29 & 1201 & 50 & $7 \%$ & $89 \%$ \\
30 to 39 & 528 & 15 & $3 \%$ & $92 \%$ \\
40 to 49 & 503 & 11 & $3 \%$ & $95 \%$ \\
over 50 & 777 & 12 & $5 \%$ & $100 \%$ \\
\hline Total & 17054 & 5371 & $100 \%$ & \\
\hline
\end{tabular}

\section{Estimation results}

\subsection{Models using continuous distance variables}

Columns 1 and 2 in table 4 provide the results of our basic specification. We use the natural log of the transaction price as the dependent variable. Distance to water is included untransformed. apart from the fixed effects referring to the homogeneous groups, parcel size is the only other explanatory variable. In column 1, where we make no distinction between types of open water, we find a significant negative effect of the distance to water on the housing price. This effect is much smaller than the values reported in past studies, and it means that every additional meter distance from a body of water is expected to decrease housing transaction price by about $0.01 \%$. Although this value is statistically significant, it is extremely small, and its economic significance is almost negligible.

In column 2 we distinguish between two types of open water: lakes and waterways. The estimated effect for proximity to a lake is statistically insignificant, but that of proximity to other water ways is significant, and even smaller than in the first regression. Both regressions provide evidence that the effect of proximity to water was biased positively in past studies, and that controlling for unobserved differences in housing and site characteristics strongly reduced the 
Table 4: Regression results Distance from water as linear and logarithm variable

\begin{tabular}{|c|c|c|c|c|}
\hline VARIABLES & $\begin{array}{c}(1) \\
\text { All watertypes }(\log ) \\
\text { no dist. limit } \\
\ln (\text { Transaction price) }\end{array}$ & $\begin{array}{c}(2) \\
\text { Lakes waterways (log) } \\
\text { no dist. Limit } \\
\ln \text { (Transaction price) }\end{array}$ & $\begin{array}{c}(3) \\
\text { All watertypes (log) } \\
\text { no dist. limit } \\
\text { ln (Transaction price) }\end{array}$ & $\begin{array}{c}(4) \\
\text { Lakes waterways (log) } \\
\text { no dist. limit } \\
\text { ln (Transaction price) }\end{array}$ \\
\hline Distance to all watertypes & $\begin{array}{c}\mathbf{- 8 . 5 9 e - 0 5 * * *} \\
(2.55 \mathrm{e}-05)\end{array}$ & & & \\
\hline Distance to lake & & $\begin{array}{c}-3.22 \mathrm{e}-05 \\
(2.08 \mathrm{e}-05)\end{array}$ & & \\
\hline Distance to waterway & & $\begin{array}{c}-\mathbf{5 . 7 0 e - 0 5 * * *} \\
(2.14 \mathrm{e}-05)\end{array}$ & & \\
\hline Distance to all watertypes $(\log )$ & & & $\begin{array}{c}-0.0119^{* * *} \\
(0.00240)\end{array}$ & \\
\hline Distance to lake (log) & & & & $\begin{array}{c}-\mathbf{0 . 0 1 0 4} * * \\
(0.00455)\end{array}$ \\
\hline Distance to waterway $(\log )$ & & & & $\begin{array}{c}-0.0107 * * * \\
(0.00245)\end{array}$ \\
\hline Parcel Size & $\begin{array}{c}\mathbf{0 . 0 0 1 0 1} * * * \\
(5.58 \mathrm{e}-05)\end{array}$ & $\begin{array}{c}\mathbf{0 . 0 0 1 0 1} * * * \\
(5.55 \mathrm{e}-05)\end{array}$ & $\begin{array}{c}\mathbf{0 . 0 0 1 0 0 0 * * *} \\
(5.41 \mathrm{e}-05)\end{array}$ & $\begin{array}{c}0.001000^{* * *} \\
(5.38 \mathrm{e}-05)\end{array}$ \\
\hline Constant & $\begin{array}{c}\mathbf{1 1 . 9 5 * * *} \\
(0.0168)\end{array}$ & $\begin{array}{c}\mathbf{1 1 . 9 7} * * * \\
(0.0195)\end{array}$ & $\begin{array}{c}11.99^{* * *} \\
(0.0184)\end{array}$ & $\begin{array}{c}\mathbf{1 2 . 0 5 * * *} \\
(0.0326)\end{array}$ \\
\hline Year Dummies & Yes & Yes & Yes & Yes \\
\hline Observations & 14,334 & 14,334 & 14,334 & 14,334 \\
\hline R-squared & 0.358 & 0.357 & 0.360 & 0.360 \\
\hline Number of groups & 2,651 & 2,651 & 2,651 & 2,651 \\
\hline $\begin{array}{l}\text { Robust standard errors in parentheses } \\
{ }^{* * *} \mathrm{p}<0.01,{ }^{* *} \mathrm{p}<0.05,{ }^{*} \mathrm{p}<0.1\end{array}$ & & & & \\
\hline
\end{tabular}

absolute value of the estimated coefficients. Indeed, our results suggest that the remaining impact of water is economically insignificant.

The results of the first specification can be criticized as insufficient for conclusions. The assumption of the model, according to which every additional meter distance from water has the same constant effect on housing prices, may be inappropriate as it is likely that the effect of proximity to water weakens after farther distances. Therefore, as an additional device to help us determine which functional form is most appropriate, we performed a Box-Cox transformation (Box and Cox, 1964) of the model in equation as following:

$$
\begin{aligned}
& P_{i}^{(\Theta)}=\frac{P_{i}^{\theta}-1}{\theta} \quad d_{i}^{(\lambda)}=\frac{d_{i}^{\lambda}-1}{\lambda} \\
& P_{i}^{(\Theta)}=\alpha+\beta_{d} d_{i}^{(\lambda)}+\beta_{z} \tilde{Z}_{i}+\sum_{t}^{T} \beta_{t} \tilde{Y_{t, i}}+\epsilon_{i}
\end{aligned}
$$

The results of the transformation are specified in table 5 . The estimated values of parameters $\theta$ and $\lambda$ are small and relatively close to zero. Although these values are significantly different from zero, they still imply that a linear specification of both the explained and explanatory distance variables is inappropriate, and that a logarithmic specification of both variables should be tested in the model. Using a logarithmic specification is also useful in order to estimate its elasticity with respect to the housing transaction prices. The results are specified in columns 3 and 4 of table 4 .

The result in column 3 shows that price-distance elasticity, with respect to all water body types, is estimated to be -0.012 . This implies that one 
Table 5: Results of the Box-Cox transformation

\begin{tabular}{|c|c|c|}
\hline & $\begin{array}{l}\text { (1) } \\
\text { All watertypes } \\
\text { Box cox }\end{array}$ & $\begin{array}{c}(2) \\
\text { Lakes waterways } \\
\text { Box cox }\end{array}$ \\
\hline $\begin{array}{l}\text { Lambda (box cox transformation of the } \\
\text { explanatory variable - Distance to water) }\end{array}$ & $\begin{array}{c}\mathbf{0 . 0 9 8 9} \\
(0.0551)\end{array}$ & $\begin{array}{c}-\mathbf{0 . 3 4 8} * * * \\
(0.0568)\end{array}$ \\
\hline $\begin{array}{l}\text { Theta (box cox transformation of the } \\
\text { explined variable - Transaction price) }\end{array}$ & $\begin{array}{c}-\mathbf{0 . 1 3 6} * * * \\
(0.0197)\end{array}$ & $\begin{array}{c}-\mathbf{0 . 1 9 7} * * * \\
(0.0229)\end{array}$ \\
\hline Untransformed explanatory variables included & Year dummies, Parcel size & \\
\hline Observations & 13,217 & 10,510 \\
\hline $\mathrm{LR} \chi^{2}$ & 7194 & 5267 \\
\hline Prob $>\chi^{2}$ & 0 & 0 \\
\hline
\end{tabular}

percentage increase in distance is expected to reduce the housing transaction price by approximately $-0.012 \%$. After making the distinction between the two examined water body types (column 4), the estimated value of the pricedistance elasticity remains almost the same, at roughly -0.01 for both lakes and waterways. These small but statistically significant values are compatible with the results of the previous specification in the sense that the estimated values are statistically significant but much smaller than what was found in previous studies. Furthermore, comparing corresponding values of distances from water and expected prices emphasizes that distance increments in closer proximities may have a stronger effect compared with farther distances.

\subsection{Using a threshold}

One concern with the estimates just reported is that they contain many properties that are so far removed from water that no impact should be expected. As noted in Lansford and Jones (1995), if proximity to water has an impact only within a certain distance range, then including properties located at a greater distance to water in the sample will result in bias towards zero of the estimated coefficient. To account for that, we estimate the model again, this time considering that the maximum distance from water is 60 meters. More explicitly, we transform the distance $d_{i}$ to a new variable $d_{i}^{*}$ as following:

$$
d_{i}= \begin{cases}d_{i} & \text { if } d_{i} \leq 60 \\ 60 & \text { if } d_{i}>60\end{cases}
$$

This new distance variable implies that only differences in proximity to water in the interval $0-60 \mathrm{~m}$ are taken into account. We should emphasize that this threshold is relatively small compared with the maximum distance of 4,000 feet (roughly 1200 meters) which was defined by Lansford and Jones. We motivate the setting of the threshold at 60 meter first by examining the distribution of properties by distance to water. Since $45 \%$ of the properties in the sample 
are located within 60 meters of any type of water, the maximum range is still relatively close to water and therefore permits identification of the effect in near proximities. The choice of 60 meter as the threshold distance was also made after experimenting with several other threshold values between 50 and 100 meters. The differences in estimated coefficients between the thresholds were quite small. $^{1}$

The value of all estimated coefficient for proximity to water in absolute distance has indeed increased, and the coefficient of distance to any type of open water in column 1 of table 6 is more than seven times as large as in table 4 . In the second column of table 6 we distinguish between lakes and other types of open water, and now we find significant coefficients for both classes. Although these coefficients are also much higher the one referring to lakes is increased by a factor 30 it is still the case that the estimated values are quite low. Additional distance of $1 \mathrm{~m}$ from any type of water is now estimated to reduce the value of the house by $0.06 \%$ (or by $0.6 \%$ for every additional 10 meters), while a $1 \mathrm{~m}$ increase in the distance to a lake or other type of open water reduces the value by $0.11 \%$ and $-0.06 \%$, respectively. The distance threshold has also increased the estimated coefficients in the distance logarithm specifications, as seen in columns 3 and 4 of table 6 . The implied distance-elasticity under a threshold limit is estimated at roughly -0.015 for both water types. This value is only slightly higher compared with the elasticity values of around -0.012 which was previously estimated in table 4 .

Table 6: Thresholds for the distance to open water

\begin{tabular}{|c|c|c|c|c|}
\hline & (1) & (2) & (3) & (4) \\
\hline VARIABLES & $\begin{array}{l}\text { All watertypes }(\log ) \\
\text { dist. limit - 60meter } \\
\ln \text { (Transaction price) }\end{array}$ & $\begin{array}{l}\text { Lakes and waterways }(\log ) \\
\text { dist. limit - 60meter } \\
\ln \text { (Transaction price) }\end{array}$ & $\begin{array}{l}\text { All watertypes }(\log ) \\
\text { dist. limit - 60meter } \\
\ln \text { (Transaction price) }\end{array}$ & $\begin{array}{l}\text { Lakes and waterways }(\log ) \\
\text { dist. limit - 60meter } \\
\ln \text { (Transaction price) }\end{array}$ \\
\hline Distance to All watertypes & $\begin{array}{c}-\mathbf{- 0 . 0 0 0 6 6 2 * * *} \\
(0.000146)\end{array}$ & & & \\
\hline Distance to lake & & $\begin{array}{c}-0.00111^{* *} \\
(0.000530)\end{array}$ & & \\
\hline Distance to waterway & & $\begin{array}{c}-0.000576^{* * *} \\
(0.000140)\end{array}$ & & \\
\hline Distance to All watertypes $(\log )$ & & & $\begin{array}{c}-\mathbf{0 . 0 1 5 2} * * * \\
(0.00399)\end{array}$ & \\
\hline Distance to lake $(\log )$ & & & & $\begin{array}{r}-\mathbf{0 . 0 1 5 6} \\
(0.0102)\end{array}$ \\
\hline Distance to waterway $(\log )$ & & & & $\begin{array}{c}-\mathbf{0 . 0 1 4 8 * * *} \\
(0.00413)\end{array}$ \\
\hline Parcel Size & $\begin{array}{c}\mathbf{0 . 0 0 1 0 0 * * *} \\
(5.17 \mathrm{e}-05)\end{array}$ & $\begin{array}{c}0.00100^{* * *} \\
(5.17 \mathrm{e}-05)\end{array}$ & $\begin{array}{c}\mathbf{0 . 0 0 0 9 9 8 * * *} \\
(5.24 \mathrm{e}-05)\end{array}$ & $\begin{array}{c}0.000998^{* * *} \\
(5.22 \mathrm{e}-05)\end{array}$ \\
\hline Constant & $\begin{array}{c}\mathbf{1 2 . 0 0 * * *} \\
(0.0217)\end{array}$ & $\begin{array}{c}\mathbf{1 2 . 0 6 * * *} \\
(0.0382)\end{array}$ & $\begin{array}{c}\mathbf{1 2 . 0 2} * * * \\
(0.0261)\end{array}$ & $\begin{array}{c}12.09^{* * *} \\
(0.0509)\end{array}$ \\
\hline Year Dummies & Yes & Yes & Yes & Yes \\
\hline Observations & 14,334 & 14,334 & 14,334 & 14,334 \\
\hline R-squared & 0.360 & 0.360 & 0.360 & 0.360 \\
\hline Number of groups & 2,651 & 2,651 & 2,651 & 2,651 \\
\hline $\begin{array}{l}\text { Robust standard errors in parentheses } \\
* * * \mathrm{p}<0.01,{ }^{* *} \mathrm{p}<0.05,{ }^{*} \mathrm{p}<0.1\end{array}$ & & & & \\
\hline
\end{tabular}

\footnotetext{
${ }^{1}$ The estimated results for $50-100 \mathrm{~m}$ thresholds are reported in appendix B.10.
} 


\subsection{Models using distance dummy variables}

In this section we will further explore the nature of the relationship between proximity to water and housing prices, by introducing further flexibility to the fixed-effects regression model. We will now specify the price of housing as a piecewise constant function of the proximity to water. we estimate the impact of proximity to water within each $10 \mathrm{~m}$ distance interval in a completely flexible way. The results in column 1 of table 7 exhibit that the effect of proximity to water is generally weakened gradually with distance. The effect of water on housing prices in the nearest $10 \mathrm{~m}$ is estimated to be approximately $4.7 \%$. It drops in the 20-30 meters range to approximately $2 \%$, and to about $1 \%$ in the $30-40$ range. In the 40-50 meter distance range, the effect of proximity to water becomes very small and statistically insignificant.

Table 7: Piecewise constant price function

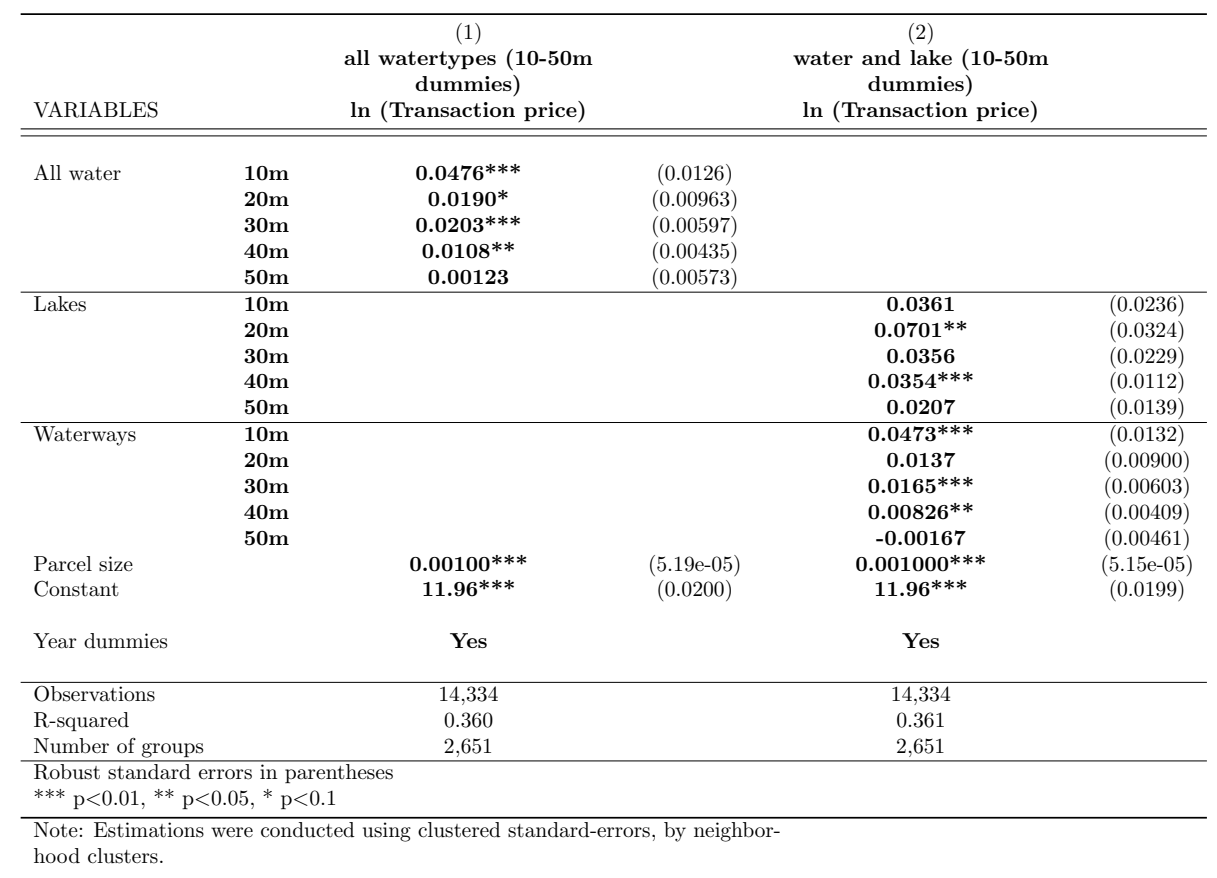

These results confirm that proximity to water indeed have an extremely local effect, and that the threshold of $60 \mathrm{~m}$ which we used above was sufficient to capture the declining effect of distance from water on housing prices. The results for specific types of water bodies, which are described in column 2, support this evidence. The effect of proximity to waterways present a pattern of decline in value with distance from water. For the properties which are nearest to waterways, the effect of water is estimated at about $4.7 \%$, and then quickly drops to $1.6 \%$ and $0.8 \%$ in the $20-40 \mathrm{~m}$ intervals. The effect becomes negative but statistically insignificant after $40 \mathrm{~m}$. The effects of proximity to a lake show 
a somewhat more subtle decline. Considering that only two of the distance intervals' coefficients are statistically significant, and that the estimation is based on a relatively lower number of observations (only $5.5 \%$ of the sample have a distance of less than 60 meters from a lake, see table 1), makes the identification of a trend more difficult. Except for a strong and significant effect of $7 \%$ in the $10-20 \mathrm{~m}$ interval, the effects of proximity to a lake maintain a relatively stable coefficient value of around $3.5 \%$ between $0-40 \mathrm{~m}$. between $40-50$ meters the coefficient value drops to approximately $2.0 \%$.

\subsection{Semi-parametric analysis}

In order to get a clearer picture of the pattern of the effect of water on housing prices, we include a semi-parametric model estimation. The use of a semi-parametric model is useful in pointing out which of the discussed functional forms that was tested above is most suitable to describe the relationship between distance from water and housing price. After removing functional forms restrictions, the analysis provides a most flexible estimation of the relationship between the proximity to water and house price. The semi-parametric analysis is estimated based on Robinson's double residual estimation (Robinson, 1988) and is specified in equation 3 . The results are presented in figures 1,23 .

Figure 1: Semi-parametric regression of House price on distance from water

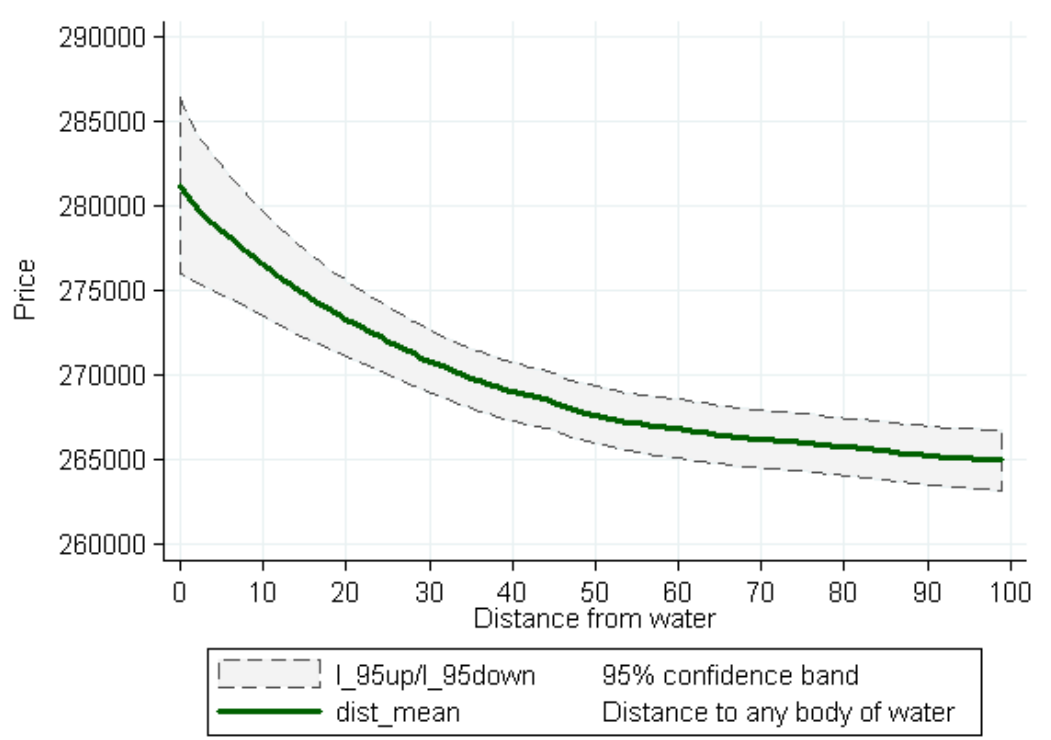

The results in figure 1 show that the effect of proximity to water is strongest in immediate proximities, and then it gradually declines until it becomes unnoticeable after 75-100 meters. The marginal effect of distance from water on housing prices at the first meter is estimated at roughly $0.28 \%$ of the mean 
Figure 2: Semi-parametric regression of House price on distance from waterways.

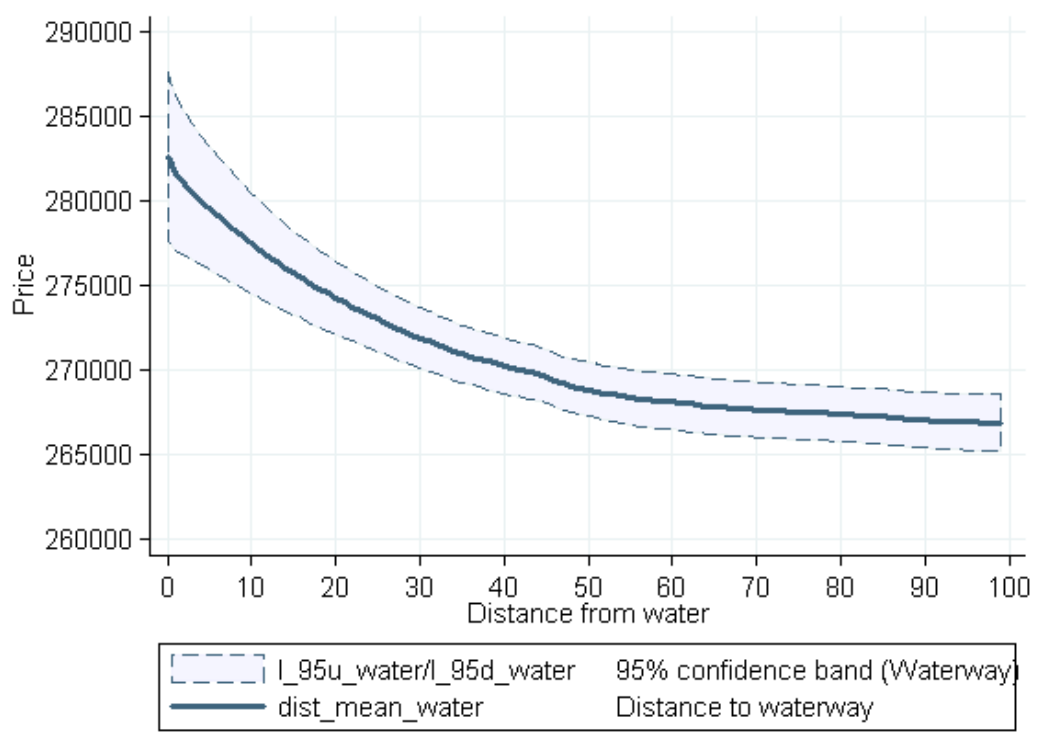

Figure 3: Semi-parametric regression of House price on distance from lakes.

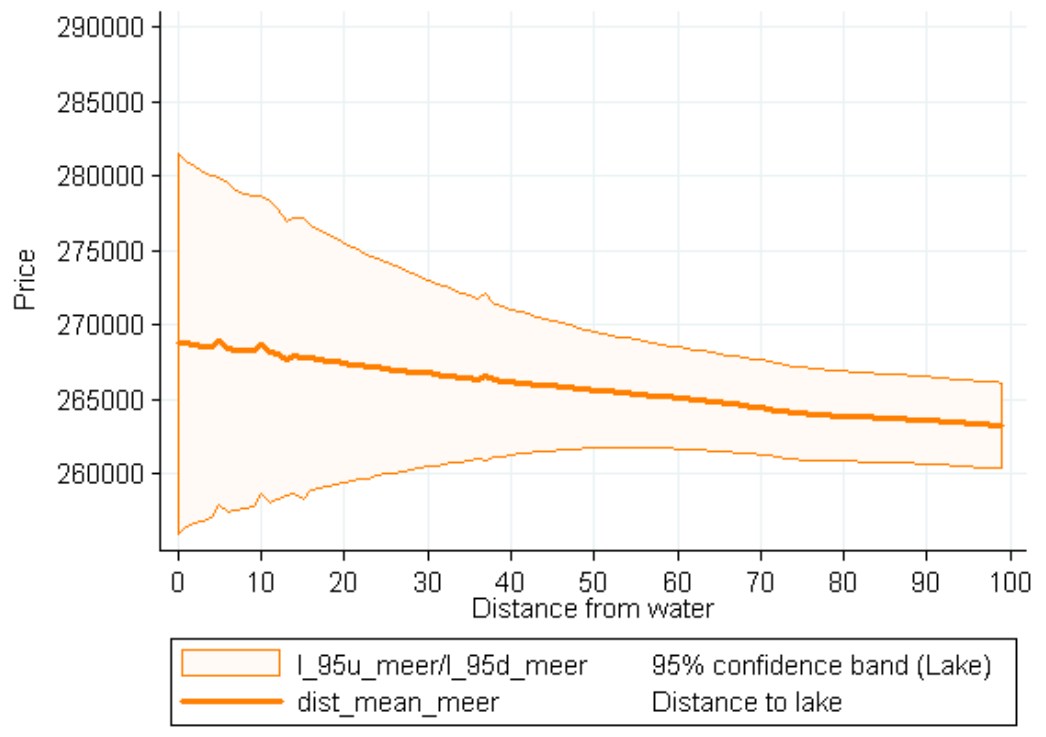


housing value ${ }^{2}$. This value can be interpreted as the marginal willingness to pay for residing one meter closer to any type of water (measured at the first meter distance). For the mean house value, this marginal effect is equivalent to approximately $€ 780$.

The marginal value of proximity to all water types decreases with distance and becomes $0.13 \%$ after 10 meters, and $0.03 \%$ after 50 meters. This is equivalent to a respective value of $€ 378$ and $€ 108$ for a property with a mean value. This finding matches the previous parametric models, which also showed a similar steady decline of the effect of water in further distances.

The results of the semi-parametric analysis for waterways (Figure 2) also show a similar pattern of decline in the strength of the estimated effect, and the effects become insignificant after approximately 75-100 meters. The marginal willingness to pay at the first meter distance to a waterway is estimated at $0.33 \%$ of the housing price, which is roughly $€ 935$ at the mean value. For 10 meters distance and 50 meters distance, these values drop to a respective $0.14 \%$ and $0.04 \%$ (or $€ 391$ and $€ 114$ ).

As was predicted by the results of the log-log model and the distance dummies model, the semi-parametric analysis produces relatively large confidence bands which indicate that the effect of distance to lake is not significantly different from zero (see figure 3 ). As lakes usually have a higher recreational value, these results are somewhat unexpected. One possible explanation for this is that there are relatively few observations within 60 meters from a lake. Moreover, unlike waterways, lakes are usually located at the edge of residential areas. Therefore, even if we consider that some residential areas are relatively more dependent in car travel for commuting purposes, proximity to a lake may still imply that a property is relatively remote and has poorer accessibility to other local services. This may have a negative effect on the prices of houses which are located closer to lakes. Another explanation may be that the definition of lakes is relatively broad and may include different bodies of water with various depth and environmental or recreational development (e.g recreational lakes and natural shallow ponds). Difference in valuations of such water bodies may cause a bias in the estimated coefficients.

\subsection{Summary of results and marginal effects}

The models which were estimated above describe different functional relationship between proximity to water and housing value. Although the majority of the estimated coefficients are found to be strongly significant and comparable with each other, they correspond with different interpretations of the marginal effects. Table 8 provides a summary of these implicit 'premiums' or willingness-to-pay values of residing next to water, and attempts to make a comparison between them. While the distance-dummies model coefficients are directly interpreted as

\footnotetext{
${ }^{2}$ Housing values noted here are computed based on the predicted smoothed value of housing price from the results of the semi-parametric regression, and they reflect the mean predicted value obtained from 200 bootstrap sampling replicates.
} 
Table 8: Willingness to pay values for proximity to water - model comparison

\begin{tabular}{|c|c|c|c|c|c|c|c|}
\hline & \multirow[b]{2}{*}{ Model } & \multicolumn{2}{|l|}{$0-1$ meters } & \multicolumn{2}{|l|}{ 1-10 meters } & \multicolumn{2}{|l|}{$40-50$ meters } \\
\hline & & $\begin{array}{l}\text { Implicit } \\
\text { value (EUR) }\end{array}$ & $\begin{array}{l}\text { Percentage } \\
\text { of housing } \\
\text { value }\end{array}$ & $\begin{array}{l}\text { Implicit } \\
\text { value (EUR) }\end{array}$ & $\begin{array}{l}\text { Percentage } \\
\text { of housing } \\
\text { value }\end{array}$ & $\begin{array}{l}\text { Implicit } \\
\text { value (EUR) }\end{array}$ & $\begin{array}{l}\text { Percentage } \\
\text { of housing } \\
\text { value }\end{array}$ \\
\hline \multirow{4}{*}{$\begin{array}{l}\text { Any type } \\
\text { of water }\end{array}$} & $\log \operatorname{lin} \star$ & $4.04 \%$ & $11,267.2$ & $3.38 \%$ & $9,420.1$ & $1.39 \%$ & $3,878.9$ \\
\hline & $\log \log \star$ & $7.15 \%$ & $19,945.3$ & $2.69 \%$ & $7,505.8$ & $0.64 \%$ & $1,774.1$ \\
\hline & dummies $\star \star$ & & & $4.76 \%$ & $13,263.8$ & $0.12 \%$ & 343.5 \\
\hline & semipar & $5.10 \%$ & $14,350.3$ & $4.23 \%$ & $11,781.3$ & $0.52 \%$ & $1,402.4$ \\
\hline \multirow[t]{4}{*}{ Lakes } & $\log \operatorname{lin} \star$ & $6.79 \%$ & $18,918.4$ & $5.67 \%$ & $15,817.0$ & $2.34 \%$ & $6,512.9$ \\
\hline & $\log \log \star$ & $7.33 \%$ (ns) & $20,446.4(\mathrm{~ns})$ & $2.76 \%(\mathrm{~ns})$ & $7,694.4(\mathrm{~ns})$ & $0.65 \%$ (ns) & $1,818.7(\mathrm{~ns})$ \\
\hline & dummies $\star \star$ & & & $3.61 \%(\mathrm{~ns})$ & $10,068.7(\mathrm{~ns})$ & $2.07 \%(\mathrm{~ns})$ & $5,763.7(\mathrm{~ns})$ \\
\hline & semipar & $1.29 \%$ & $3,609.8$ & $1.22 \%$ & $3,405.0$ & $0.26 \%$ & 720.0 \\
\hline \multirow[t]{4}{*}{ Waterways } & $\log \operatorname{lin} \star$ & $3.52 \%$ & $9,801.9$ & $2.94 \%$ & $8,195.1$ & $1.21 \%$ & $3,374.4$ \\
\hline & $\log \log \star$ & $6.95 \%$ & $19,371.0$ & $2.61 \%$ & $7,289.7$ & $0.62 \%$ & $1,723.0$ \\
\hline & dummies $\star \star$ & & & $4.73 \%$ & $13,197.6$ & $-0.17 \%$ (ns) & $-466.0(\mathrm{~ns})$ \\
\hline & semipar & $5.18 \%$ & $14,455.1$ & $4.15 \%$ & $11,571.9$ & $0.47 \%$ & $1,323.9$ \\
\hline
\end{tabular}

Notes: $\star$ The values are based on the $60 \mathrm{~m}$ threshold models

$\star \star$ Distance-dummies model indicates a dummy variable for 0-10 meters.

Implicit values in Euro are calculated based on house value of $278,800 €$, which is the mean house value in the sample.

(ns) indicates that the estimated coefficient is not significant at $5 \%$ level.

the willingness-to-pay for residing in a particular distance range from water, the coefficients of the other parametric models provide marginal effects of additional meter or percentage distance from water. In order to make them comparable with the distance-dummies, we calculated the premium of residing close to water by adding the effects from the appropriate distance intervals to the 60 meter threshold. The results of the semi-parametric analysis were adjusted similarly, by comparing the mean predicted smoothed value of housing prices in different proximities to water with the predicted house value at the 60 meter threshold.

The comparison shows that all models result in a significant premium for residing directly next to water (0-1 meter distance from water). Expectedly, the log-log model presents the highest value, most likely due to the model's sensitivity to small values. Focusing on the semi-parametric model, results show that houses in immediate proximity to water are valued approximately $5.1 \%$ more than houses located on the $60 \mathrm{~m}$ threshold or farther away. With respect to the mean housing value, this percentage is equivalent to about $€ 14,400$.

Results from all models show that the willingness-to-pay values decrease with distance. Houses which are located within 10 meters from water are valued roughly $2.6-4.7 \%$ more than houses with no proximity to water. The decline between 0-1 meters and 1-10 meters is explained by the fact that not all houses in the latter range may enjoy a view to the water, and most likely do not have direct (private) access to water, which may effect their willingness-to-pay.

The effects of proximity to water becomes significantly smaller after 40 meters distance and are hardly apparent. Although the results of the log-linear model show that proximity to a lake in this distance range is still expected to increase housing value by about $2.2 \%$, the majority of the models predict that the willingness to pay for proximity to water in these distance ranges is relatively close to zero. 


\section{Conclusion}

In this research we exploited data from new residential developments in a large number of neighborhoods the Netherlands, and conducted a fixed effects analysis to explore the relationship between proximity to water and housing value. Our fixed effects refer to houses that are technically identical and located very close to each other (often literally next to each other as many houses are terraced). By controlling for fixed effects we were able to better identify the effects of proximity to water, and to avoid a potential positive bias which results from the tendency of houses that are located closer to water to be more luxurious, and therefore more expensive. In addition, we estimated several parametric and semi-parametric model specifications in order to shed light on the pattern relationship between proximity to water and housing prices. The estimation results from the specified models and the calculations of the marginal effects and water-premiums show that the effect of proximity to water on housing prices is smaller compared with the values which were reported in past studies. This provides evidence that control for fixed-effect is necessary in order to reduce the positive estimator bias of proximity to water.

The results of the models which were presented raise several issues. First, the effect of proximity to water, as estimated in the specifications above, is smaller compared to results from previous studies. We find that proximity to water increases housing value by roughly $5 \%$ at the most immediate proximities to water. This finding strengthens our argument that a tendency to develop higher quality residential housings in close proximity to water may previously led to a positive bias in the estimated effect of proximity to water.

Second, there are differences between the valuations of different water body types. Based on the log-linear model, proximity to lakes seems to be valued slightly higher than proximity to waterways, and it also decreases slower with the distance. However, the results of the distance dummy model show that while positive effects are estimated in certain distance intervals, it is difficult to identify a clear trend of price decline with distance from lakes. This is also evident from the log-log model and the semi-parametric analysis, in which the effects of proximity to lake are not significantly different from zero.

Third, All models point out that the effect of proximity to water is extremely local and evident mostly in very close proximities to water. The effect of water becomes weaker and gradually decreases with distance until it becomes small

and statistically insignificant, after approximately 60 meters distance from all water types.

\section{Acknowledgement}

We would like to thank Jos van Ommeren and Hans Koster for their useful and insightful comments. 


\section{References}

Anderson, S. T., West, S. E., Nov. 2006. Open space, residential property values, and spatial context. Regional Science and Urban Economics 36 (6), 773-789.

Box, G., Cox, D., 1964. An analysis of transformations. Journal of the Royal Statistical Society, Series B 26 (2), 211-252.

Bryant, L., Eves, C., 2013. Data requirements of hedonic models in determining the impact of infrastructure charges on new housing costs. In: RICS Cobra 2013 Conference, Royal Institution of Chartered Surveyors.

Cheshire, P., Sheppard, S., 1995. On the price of land and the value of amenities. Economica 62 (246), 247-267.

Cho, S., Bowker, J., Park, W., 2006. Measuring the contribution of water and green space amenities to housing values: An application and comparison of spatially weighted hedonic models. Journal of agricultural and resource economics 31 (3), 485-507.

Doss, C., Taff, S., 1996. The influence of wetland type and wetland proximity on residential property values. Journal of agricultural and resource economics 21 (1), 120-129.

Efron, B., 1979. Bootstrap methods: another look at the jackknife. The annals of Statistics 7 (1), 1-26.

Geoghegan, J., Wainger, L. a., Bockstael, N. E., Dec. 1997. Spatial landscape indices in a hedonic framework: an ecological economics analysis using GIS. Ecological Economics 23 (3), 251-264.

Goetgeluk, R., Kauko, T., Priemus, H., Jan. 2005. Can Red Pay for Blue? Methods to Estimate the Added Value of Water in Residential Environments. Journal of Environmental Planning and Management 48 (1), 103-120.

Halvorsen, R., Pollakowski, H., 1981. Choice of functional form for hedonic price equations. Journal of Urban Economics 49, 37-49.

Kuminoff, N. V., Parmeter, C. F., Pope, J. C., Nov. 2010. Which hedonic models can we trust to recover the marginal willingness to pay for environmental amenities? Journal of Environmental Economics and Management 60 (3), $145-160$.

Lansford, N. J., Jones, L., 1995. Recreational and aesthetic value of water using hedonic price analysis. Journal of Agricultural and Resource Economics 20 (2), $341-355$.

Luttik, J., 2000. The value of trees, water and open space as reflected by house prices in the Netherlands. Landscape and Urban Planning 48, 161-167. 
Mahan, B. L., Polasky, S., Adams, R. M., 2000. Valuing urban wetlands: a property pricing approach. Land Economics 76 (1), 100-113.

Orford, S., 2002. Valuing locational externalities: a GIS and multilevel modelling approach. Environment and Planning B: Planning and Design 29 (1), 105-127.

Robinson, P., 1988. Root-N-consistent semiparametric regression. Econometrica: Journal of the Econometric Society 56 (4), 931-954. 


\section{AppendixA. List of Neighborhoods in the research}

Table A.9: List of Neighborhoods in the research

\begin{tabular}{|c|c|c|c|c|c|}
\hline$\#$ & City & Neighbourhood & $\#$ & City & Neighbourhood \\
\hline 1 & Alkmaar & Vroonermeer-Zuid & 58 & Helmond & Schutsboom \\
\hline 2 & Almelo & Kollenveld-Bolkshoek & 59 & Helmond & Stepekolk \\
\hline 3 & Almelo & Nijrees & 60 & Hengelo Ov & Het Broek \\
\hline 4 & Almere & De Velden & 61 & Hoofddorp & Floriande-Oost \\
\hline 5 & Almere & Eilandenbuurt & 62 & Hoofddorp & Floriande-West \\
\hline 6 & Almere & Indischebuurt & 63 & Hooglanderveen & Eindweg en Landweg \\
\hline 7 & Almere & Literatuurwijk & 64 & Krommenie & Willis \\
\hline 8 & Almere & Noorderplassen & 65 & Leeuwarden & Havankpark \\
\hline 9 & Almere & Oostvaardersbuurt & 66 & Leeuwarden & Hemrik \\
\hline 10 & Almere & Seizoenenbuurt & 67 & Leeuwarden & Zuiderburen \\
\hline 11 & Almere & Sieradenbuurt & 68 & Leiden & Roomburg \\
\hline 12 & Almere & Stripheldenbuurt & 69 & Lelystad & De Landerijen \\
\hline 13 & Almere & Tussen de Vaarten Noord & 70 & Lelystad & Flevopoort \\
\hline 14 & Almere & Tussen de Vaarten Zuid & 71 & Lelystad & Golfresort-Zuigerplasbos \\
\hline 15 & Almere & Verspreide huizen Almere-Stad & 72 & Lelystad & Hollandse Hout \\
\hline 16 & Amersfoort & Birkhoven en Bokkeduinen & 73 & Lelystad & Houtribhoogte-Parkhaven \\
\hline 17 & Amersfoort & Centrum & 74 & Lelystad & Landstrekenwijk \\
\hline 18 & Amersfoort & Laak-Zuid & 75 & Nieuw Vennep & Nieuw-Vennep-Getsewoud-Noord \\
\hline 19 & Amersfoort & Lint-Oost & 76 & Nieuw Vennep & Nieuw-Vennep-Getsewoud-Zuid \\
\hline 20 & Amersfoort & Stadstuin & 77 & Nymegen & Oosterhout \\
\hline 21 & Amersfoort & Velden-Noord & 78 & Rosmalen & Broekland \\
\hline 22 & Amersfoort & Velden-Zuid & 79 & Rosmalen & De Watertuinen \\
\hline 23 & Amersfoort & Waterkwartier & 80 & Rotterdam & Nesselande \\
\hline 24 & Apeldoorn & Schoonlocht & 81 & S Gravenhage & Bosweide \\
\hline 25 & Arnhem & Schuytgraaf-Noord & 82 & $\mathrm{~S}$ Gravenhage & De Bras \\
\hline 26 & Arnhem & Schuytgraaf-Zuid & 83 & $\mathrm{~S}$ Gravenhage & De Lanen \\
\hline 27 & Assendelft & Parkrijk & 84 & S Gravenhage & De Velden \\
\hline 28 & Assendelft & Waterrijk & 85 & S Gravenhage & De Vissen \\
\hline 29 & Breda & Heilaar & 86 & S Gravenhage & Erasmus Veld \\
\hline 30 & Breda & Kroeten & 87 & S Gravenhage & Hoge Veld \\
\hline 31 & Breda & Steenakker & 88 & S Gravenhage & Lage Veld \\
\hline 32 & Breda & Waterdonken & 89 & S Gravenhage & Morgenweide \\
\hline 33 & De Meern & Veldhuizen & 90 & S Gravenhage & Parkbuurt Oosteinde \\
\hline 34 & Delft & Bedrijventerrein Zuideinde & 91 & S Gravenhage & Singels \\
\hline 35 & Delft & Buitenhof-Zuid & 92 & S Gravenhage & Waterbuurt \\
\hline 36 & Delft & Koningsveldbuurt & 93 & S Gravenhage & Zonne Veld \\
\hline 37 & Delft & Molenbuurt & 94 & S Hertogenbosch & De Haverleij \\
\hline 38 & Deventer & Graveland & 95 & S Hertogenbosch & Empel-Oost \\
\hline 39 & Deventer & Het Fetlaer en Spijkvoorder Enk & 96 & S Hertogenbosch & Maasakker \\
\hline 40 & Deventer & Het Jeurlink & 97 & Schiedam & Buurt 98 \\
\hline 41 & Deventer & Spikvoorde & 98 & Tilburg & Koolhoven \\
\hline 42 & Deventer & Steinvoorde & 99 & Tilburg & Witbrant \\
\hline 43 & Dordrecht & De Hoven & 100 & Utrecht & Langerak \\
\hline 44 & Dordrecht & Dordtse Hout & 101 & Utrecht & Parkwijk-Noord \\
\hline 45 & Dordrecht & Vissersdijk-Oost & 102 & Utrecht & Parkwijk-Zuid \\
\hline 46 & Ede Gld & Kernhem & 103 & Utrecht & Terwijde-West \\
\hline 47 & Eindhoven & Bos- en Zandrijk & 104 & Venlo & Hagerbroek \\
\hline 48 & Eindhoven & Bosrijk & 105 & Vleuten & Vleuterweide-Noord/Oost/Centrum \\
\hline 49 & Eindhoven & Driehoeksbos & 106 & Vleuten & Vleuterweide-West \\
\hline 50 & Eindhoven & Grasrijk & 107 & Vleuten & Vleuterweide-Zuid \\
\hline 51 & Emmen & Delftlanden & 108 & Wateringen & Parkbuurt Oosteinde \\
\hline 52 & Emmen & Parc Sandur & 109 & Zoetermeer & Oosterheem-Noordoost \\
\hline 53 & Enschede & het Brunink & 110 & Zoetermeer & Oosterheem-Zuidwest \\
\hline 54 & Groningen & Bangeweer & 111 & Zwolle & Frankhuis \\
\hline 55 & Groningen & Dorkwerd & 112 & Zwolle & Holtenbroek I \\
\hline 56 & Groningen & Stadspark & 113 & Zwolle & Millingen \\
\hline 57 & Helmond & De Veste & 114 & Zwolle & Werkeren \\
\hline
\end{tabular}




\section{AppendixB. Regression results under different thresholds}

Table B.10: Regression results under different thresholds between 50 and 100 meters from water (log-lin and log-log models)

\begin{tabular}{|c|c|c|c|c|c|c|}
\hline Distance threshold & $\begin{array}{c}(1) \\
\ln \text { any water } \\
50\end{array}$ & $\begin{array}{c}(2) \\
\text { ln any water } \\
60\end{array}$ & $\begin{array}{c}(3) \\
\text { ln any water } \\
70\end{array}$ & $\begin{array}{c}(4) \\
\text { ln any water } \\
80\end{array}$ & $\begin{array}{c}(5) \\
\text { ln any water } \\
90\end{array}$ & $\begin{array}{c}(6) \\
\text { ln any water } \\
100\end{array}$ \\
\hline Distance to water & $\begin{array}{c}-\mathbf{0 . 0 0 0 8 2 4} * * * \\
(0.000190)\end{array}$ & $\begin{array}{c}-\mathbf{0 . 0 0 0 6 6 2} * * * \\
(0.000146)\end{array}$ & $\begin{array}{c}-\mathbf{0 . 0 0 0 5 5 1 * * *} \\
(0.000114)\end{array}$ & $\begin{array}{c}-\mathbf{0 . 0 0 0 4 5 5 * * *} \\
(9.39 \mathrm{e}-05)\end{array}$ & $\begin{array}{c}-\mathbf{0 . 0 0 0 3 8 1 * * *} \\
(7.96 \mathrm{e}-05)\end{array}$ & $\begin{array}{c}-\mathbf{0 . 0 0 0 3 2 2} * * * \\
(6.96 \mathrm{e}-05)\end{array}$ \\
\hline Parcel Size & $\begin{array}{c}\mathbf{0 . 0 0 1 0 0 * * *} \\
(5.41 \mathrm{e}-05)\end{array}$ & $\begin{array}{c}\mathbf{0 . 0 0 1 0 0} * * * \\
(5.43 \mathrm{e}-05)\end{array}$ & $\begin{array}{c}\mathbf{0 . 0 0 1 0 0} \\
(5.45 \mathrm{e}-05)\end{array}$ & $\begin{array}{c}\mathbf{0 . 0 0 1 0 0} * * * \\
(5.47 \mathrm{e}-05)\end{array}$ & $\begin{array}{c}\mathbf{0 . 0 0 1 0 0} \\
(5.48 \mathrm{e}-05)\end{array}$ & $\begin{array}{c}\mathbf{0 . 0 0 1 0 1} * * * \\
(5.50 \mathrm{e}-05)\end{array}$ \\
\hline Constant & $\begin{array}{c}12.00 * * * \\
(0.0180)\end{array}$ & $\begin{array}{c}12.00 * * * \\
(0.0177)\end{array}$ & $\begin{array}{c}12.00 * * * \\
(0.0175)\end{array}$ & $\begin{array}{c}\mathbf{1 1 . 9 9} * * * \\
(0.0175)\end{array}$ & $\begin{array}{c}11.99 * * * \\
(0.0174)\end{array}$ & $\begin{array}{c}11.99 * * * \\
(0.0174)\end{array}$ \\
\hline Observations & 17,054 & 17,054 & 17,054 & 17,054 & 17,054 & 17,054 \\
\hline R-squared & 0.360 & 0.360 & 0.360 & 0.360 & 0.360 & 0.359 \\
\hline Number of vari & 5,371 & 5,371 & 5,371 & 5,371 & 5,371 & 5,371 \\
\hline \multicolumn{7}{|c|}{$\begin{array}{l}\text { Robust standard errors in parentheses } \\
* * * \mathrm{p}<0.01,{ }^{* *} \mathrm{p}<0.05,{ }^{*} \mathrm{p}<0.1\end{array}$} \\
\hline Distance threshold & $\begin{array}{c}(1) \\
\ln \text { any water } \\
50\end{array}$ & $\begin{array}{c}(2) \\
\ln \text { any water } \\
60 \\
\end{array}$ & $\begin{array}{c}(3) \\
\ln \text { any water } \\
70 \\
\end{array}$ & $\begin{array}{c}(4) \\
\ln \text { any water } \\
80\end{array}$ & $\begin{array}{c}(5) \\
\ln \text { any water } \\
90 \\
\end{array}$ & $\begin{array}{c}(6) \\
\text { ln any water } \\
100 \\
\end{array}$ \\
\hline $\begin{array}{l}\text { Distance to water } \\
(\log )\end{array}$ & $\begin{array}{c}-\mathbf{0 . 0 1 5 7} * * * \\
\quad(0.00348)\end{array}$ & $\begin{array}{c}-\mathbf{0 . 0 1 5 2} * * * \\
(0.00329)\end{array}$ & $\begin{array}{c}-\mathbf{0 . 0 1 4 9} * * * \\
\quad(0.00312)\end{array}$ & $\begin{array}{c}-\mathbf{0 . 0 1 4 5} * * * \\
(0.00300)\end{array}$ & $\begin{array}{c}-\mathbf{0 . 0 1 4 1} * * * \\
(0.00289)\end{array}$ & $\begin{array}{c}-\mathbf{0 . 0 1 3 6 * * *} \\
(0.00281)\end{array}$ \\
\hline Parcel Size & $\begin{array}{l}\mathbf{0 . 0 0 0 9 9 9} * * * \\
\quad(5.39 \mathrm{e}-05)\end{array}$ & $\begin{array}{c}\mathbf{0 . 0 0 0 9 9 8 * * *} \\
(5.39 \mathrm{e}-05)\end{array}$ & $\begin{array}{c}\mathbf{0 . 0 0 0 9 9 8 * * *} \\
(5.39 \mathrm{e}-05)\end{array}$ & $\begin{array}{l}\mathbf{0 . 0 0 0 9 9 8 * * *} \\
\quad(5.39 \mathrm{e}-05)\end{array}$ & $\begin{array}{c}\mathbf{0 . 0 0 0 9 9 8 * * *} \\
(5.39 \mathrm{e}-05)\end{array}$ & $\begin{array}{c}\mathbf{0 . 0 0 0 9 9 8 * * *} \\
(5.40 \mathrm{e}-05)\end{array}$ \\
\hline Constant & $\begin{array}{c}12.02 * * * \\
(0.0204)\end{array}$ & $\begin{array}{c}\mathbf{1 2 . 0 2}^{* * * *} \\
(0.0201)\end{array}$ & $\begin{array}{c}\mathbf{1 2 . 0 2}^{* * * *} \\
(0.0199)\end{array}$ & $\begin{array}{c}\mathbf{1 2 . 0 2}^{* * * *} \\
(0.0197)\end{array}$ & $\begin{array}{c}\mathbf{1 2 . 0 2}^{* * * *} \\
(0.0196)\end{array}$ & $\begin{array}{c}12.02 * * * \\
(0.0195)\end{array}$ \\
\hline Observations & 17,054 & 17,054 & 17,054 & 17,054 & 17,054 & 17,054 \\
\hline R-squared & 0.360 & 0.360 & 0.361 & 0.361 & 0.361 & 0.361 \\
\hline Number of vari & 5,371 & 5,371 & 5,371 & 5,371 & 5,371 & 5,371 \\
\hline $\begin{array}{l}\text { Robust standard error } \\
* * * \mathrm{p}<0.01, * * \mathrm{p}<0.0\end{array}$ & $\begin{array}{l}\mathrm{s} \text { in parentheses } \\
, * \mathrm{p}<0.1\end{array}$ & & & & & \\
\hline
\end{tabular}


AppendixC. Map of selected neighborhoods

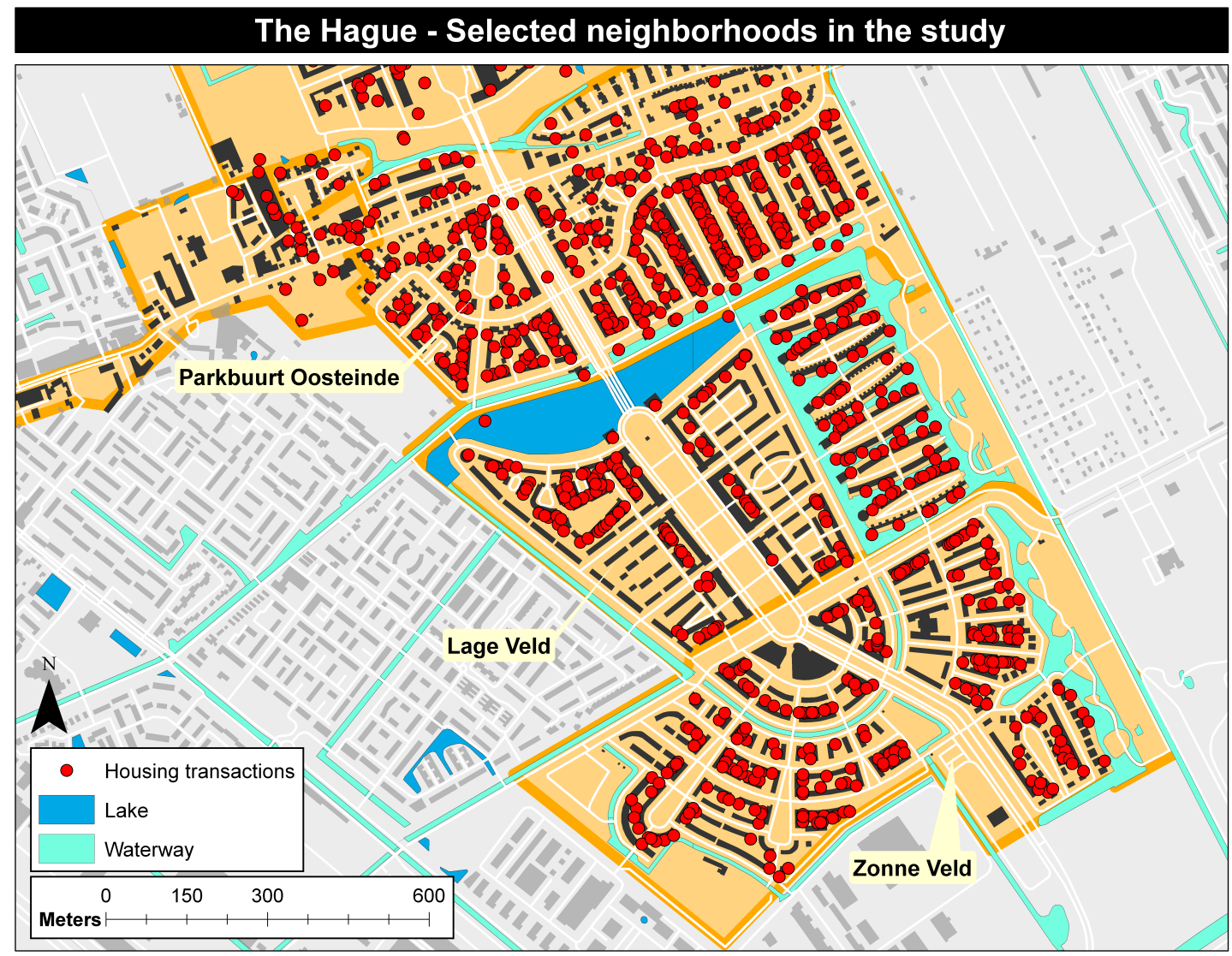

Figure C.4: Map of selected neighborhoods in the study - The Hague ('S Gravenhage / Den-Haag). 